\title{
Characteristics Of The Vowels Sequences In Muna Language
}

\author{
La Ode Sidu Marafad ${ }^{1}$ \\ Universitas Halu Oleo ${ }^{1}$ \\ \{laodesidumarafad@gmail.com ${ }^{1}$ \}
}

\begin{abstract}
This paper is entitled Characteristics of The Vowels Sequences in Muna Language. The goal to be achieved is to describe and analyze the characteristics of the series of vowels in a word. The method used is a qualitative descriptive method. The results show that there are five vowels in the Muna language, namely [i e a $\mathrm{u}$ o]. In a word, a series of vowels is a series of two vowels, [ii], such as pii "pain", a series of vowels [ie] like tiene "borders of the garden", a series of vowels [ia] like lia "cave", a series of vowels [iu] like piu "oyster", a series of vowels [io] such as lio "stick", a series of vowels [ei] such as wei "tripe", a series of vowels [ee] such as kee "narrow", a series of vowels [ea] such as rea "blood", a series of vowels [eu] such as leu "wilt", vowel series [eo] such as gholeo "day", vowel series [aa] such as laa "straight, river", vowel series [ai] like sai "strike", vowel series [ae] such as ghae "cry", a series of vowels [au] such as sau "wood", a series of vowels [ao] such as lao "wilt", a series of vowels [ui] such as lui "leathery", a series of vowels [ue] such as ue "veins", a series vowel [ua] such as wua "fruit", vowel series [uu] such as tuu "knee", vowel series [uo] such as suo "mine", vowel series [oe] such as oe "water", vowel series [ oa] like koa "owl", vowel strings [ou] tou "howl", vowel strings [oo] roo "leaves", three vowel strings [aoa] daoa "market", vowel strings [aea] waea "bat", a series of vowels [eau] bheau "candlenut", a series of vowels [aeo] taeo "reed pig", a series of vowels [uea] buea "crocodile", a series of vowels [oua] ghoghoua "navel", a series four vowels [ueue] ueue "swinging", a series of [ouou] ouou "howling", a series of five vowels [eueue] neueue "she swaying", a series of six vowels [aeueue] aeueue "I swung", a series of [aeueue] taeueue "We swing around", a series of seven vowels [aeueuea] naeueuea "He is swinging around".
\end{abstract}

Keywords: Characteristics; Muna language; Vowels

\section{Introduction}

Many regional languages live in Southeast Sulawesi, Indonesia, including: Muna, Wolio, Tolaki, Moronene, Wawonii, Kulisusu, and Wakatobi. Speakers of Muna language (ML) are called mieno Wuna 'Muna people/ethnic Muna. The number of speakers is around 400 thousand people spread across several districts and several areas outside Southeast Sulawesi. 
The narrative center is on Muna Island. ML speakers on Muna Island are found in Kendari, on Buton Island, in Kolaka, and in other parts of Indonesia.

The Muna language has much uniqueness. The uniqueness can be found in the typology. In terms of language typology, Muna is classified as a vocalist type, agglutination type, and incorporation type. However, on this occasion, the type discussed was the type of vocalist related to their characteristics. There are five interesting things about the characteristics of the vocalist type of Muna language. The five interesting things are (1) characteristic of syllables, (2) characteristics of lengthening (quantity) of vowels, (3) characteristics of consonant deletion at the end of syllables, (4) characteristics of adding vowels at the end of syllables, (5) characteristics vowel group structures in a word.

ML syllables are classified as open syllables. Each syllable ends with a vowel. For example: lambu $==>l a-m b u$ 'rumah, foreign words or loan words that have closed syllables, adjusted to be open syllables. For example, the word plate is absorbed from Indonesian into piri in Muna.

The Muna language has long vowels (ii, ee, $a a, u u, o o$ ) such as the rii word 'fairy', nee 'nose', laa 'stem, straight, river', luи 'tears', roo 'leaves'. There are also long vowels that occur from the pelting of the consonants between the two vowels. For example: the long vowel [uu] in the word puu comes from the word pughu 'tree', the consonant $g h$ is dilated.

The deletion of consonants at the end of syllables occurs from loan words or foreign words that have closed syllables or syllables that end in consonants. For example: pa-yung (Indonesian) becomes $p a-u$. Apart from impingement, there is also the addition of a vowel at the end of the syllable for loan words. Example: sen-dali $==>s a-n d a-l i$.

Characteristics of lengthening, deletion, and addition of vowels at the end of a syllable are related to the occurrence of vowel groups in a word. Vowel groups occur from two vowels to nine vowel groups. Muna language has 5 vowels [a i u e o], 17 consonants [b Б d D f g g k $1 \mathrm{~m}$ $\mathrm{n} \mathrm{p} \mathrm{p} \mathrm{r} \mathrm{s} \mathrm{t} \mathrm{w],} 7$ prenasal [mp, mb, nt, nd, ns, $\mathrm{nk}, \mathrm{ng}]$. In Muna language there are no palatal sounds [c $\mathrm{j} \breve{\mathrm{s}} \mathrm{n} \mathrm{y}]$. Palatal sounds in loan words are adjusted to the sounds of the Muna language. The sound [c] tends to be replaced with [s]: cucur $==>$ susuru. The sound [j] tends to be replaced with [dh]: Jawa $=>$ Dhawa, the sound [š] tends to be replaced with [s]: syarat $=>$ sarati, the sound $[\mathrm{y}]$ tends to be replaced with $[\mathrm{e}]:$ kebaya $==>$ kabaea, The sound $[\check{\mathrm{n}}]$ tends to be replaced by [n]: nyonya $==>$ nona .

Based on the explanation above, the uniqueness of the Muna language through the characteristics of its vowels is very interested in being used as study material. The problem raised is "What are the characteristics of the vowel sequences in Muna language?"

\section{Method}

The method used in this paper is a qualitative descriptive method. The purpose of this descriptive study is to make systematic, factual and accurate descriptions of the facts, properties and relationships between the phenomena being investigated. With this method, the data submitted can be classified, described and analyzed.

\section{Discussion}

\subsection{Syllable characters}


The syllable is the smallest rhythmic unit in the flow speech. The peak of the rhythm or rhythm is the same as loudness or sonorities, namely the reflection of the sound produced or made possible by the presence of a resonance chamber. In simple terms it can be said that the tribe the word is the part of the word that is pronounced in one breath and generally consists of several phonemes. Each language has a unique syllable character, as well as that of the Muna language. ML syllables are open syllables, either at the beginning, in the middle or at the end of the word.

Data 1
a. palenda $\longrightarrow$ pa-le-nda
'satire'
b. kakuni $\rightarrow k a-k u-n i \quad$ 'yellow'
c. sampalu $\rightarrow$ sa-mpa-lu 'tamarind'
d. tambula $\rightarrow$ ta-mbu-la 'cataract'
e. pansuru $\rightarrow$ pa-nsu-ru 'direct'

\subsection{Characteristics of Vowel Length (Quantity)}

In ML there are long vowels.

Data 2
a. soono
b. paa
'presumably'
c. laa
d. gaa
'four'
e. lee
f. tuu
'1 stick, 2 times, 3 straight'
'married'
'thriving'
g. nee
'knee'
'nose' flanked.
Data 3
a. pu ghu
b. toto

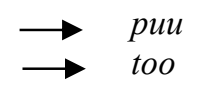
'tree'
c. kobho
$\longrightarrow k o o$
'deadline'
d. mihina
'tie'
e. wulu
$\longrightarrow$ miina
'no'
f. kala
'fur'
'go'

\subsection{Deletion of Consonants at the End of Syllables}

Consonant deletion phenomenon at the end of a syllable usually occur in loan words that contain high vowels or end phonemes nasal / $\mathrm{m}, \mathrm{n}, \mathrm{y} /$.

Data 4
a. su-mur
su-mu
'well'
b. ke-lom
ko-lo
c. pi-ring
pi-ri
d. gi-ling
gi-li
e. tu-kang
tu-ka
f. gan-deng
g. sa-bun
ga-nde
sa-bo
h. pang-gung
pang-gu 'stage'
i. ga-lon
ga-lo
'plate'
'grind'
'handyman'
'holding'
'soap'
'gallon' 


\subsection{Addition of Vowels at the End of Syllables}

The phenomenon of adding a vowel at the end of a syllable usually occurs in loan words that contain not high / low vowels or do not end with nasal phonemes / $\mathrm{m}, \mathrm{n}, \mathrm{y} /$. .

Data 5
a. ker-tas
ka-ra-ta-si 'paper'
b. se-ko-lah
si-ko-la 'school'
c. sen-dal
sa-nda-li 'slippers'
d. bo-tol
bu-to-lo
'bottle'
e. ki-per
ke-pe-re
'goalkeeper'
f. be-k
be-ke
'defender'
g. ge-ro-bak
ka-ro-bha
'cart'

3.5. Characteristics of Vowel Clusters in a Word.

Vowel clusters in a word BM, there are two vowels, three vowels, four vowels, five vowels, six vowels, and seven vowels.

Two-vowel cluster [ii, ie, ia, iu, io]

Data 6
a. pii
'pain'
b. noodle 'person'
c. wia
'torn'
d. liu
'through'
e. lio
'stick'

Data 6 shows that vowel [i] can form a cluster with all vowels [i e a u o]

Two-vowel cluster [ei, ee, ea, eu, eo]

Data 7
a. tei
b. nee
'put'
c. lea
'nose'
d. deu
'sick'
e. gholeo 'day'

Data 7 shows that vowel [e] can form clusters with all vowels [i e a u o].

Two-vowel cluster [ai, ae, aa, au, ao]

Data 8
a. dai
'broken'
b. kae
'less'
c. laa
d. sau
'stem, times'
'wood'
e. lao
'withered'

Data 8 shows that vowel [a] can form a group with all vowels [i e a u o].

Two-vowel cluster [ui, ue, ua, uu, uo]

Data 9
a. lui
'leathery'
b. ghue
'rattan'
c. жиа
'fruit'
d. tuu
'knee'
e. suo
'mine'

Data 9 shows that vowel [u] can form clusters with all vowels [i e a u o].

Two-vowel cluster [oi, oe, oa, ou, oo] 


$\begin{array}{cl}\text { Data } 10 & \\ \text { a. doi } & \text { 'money' } \\ \text { b. oe } & \text { 'water' } \\ \text { c. koa } & \text { 'owl' } \\ \text { d. tou } & \text { 'barking' } \\ \text { e. foo } & \text { 'mango' }\end{array}$

Data 10 shows that vowel [o] can form clusters with all vowels [i e a u o].

Three-vowel cluster [aea]

Data 11

$\begin{array}{ll}\text { a. waea } & \text { 'bat' } \\ \text { b. sirikaea } & \text { 'soursop' } \\ \text { c. kapaea } & \text { 'papaya' } \\ \text { d. mambaraea } & \text { 'one of a kind of bird' } \\ \text { e. santagalaea } & \text { 'python' } \\ \text { f. parasaea } & \text { 'believe' } \\ \text { g. hadaea } & \text { 'perhaps' }\end{array}$

The words waea, sirikaea, kapaea, mambaraea, santagalaea, and parasaea in the data (11) are root words that have three vowel clusters. Meanwhile, hadaea is an invented word whose root word hadae gets the postposition $\{-\mathrm{a}\}$.

Three-vowel cluster [oeo]

Data 12

a. bhokoeo 'someday, a type of shellfish'

Words that have the three-vowel structure [oeo] were found recently as shown in the data (12).

Three-vowel cluster [aeo]

Data 13

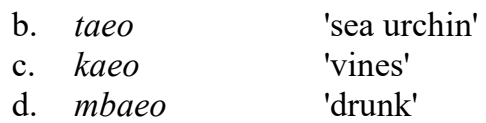

Words that have a three-vowel cluster with the structure [aeo], are very limited, as shown in data 13.

Three-vowel cluster[eau]

Data 14

a. bheau 'candlenut'

Only one word has been found that has a three-vowel structure [eau].

Three-vowel cluster [uea]

Data 15

b. buea 'crocodile'

c. kuea 'eagle'

Words that have a vowel cluster with the [uea] structure are only two words found as shown in the data (15).

Three-vowel cluster [oua]

Data 16
a. mpoua
'swinging on both legs while lying down'
b. ghoghoua
'navel'
c. pimple' soua

Words that have the three-vowel cluster [oua] are very limited. Only three words were found as shown in the data (16). 


\section{Three-vowel cluster [aue]}

Data 17
a. kaue
'swing'
b. bhaue
'swing'
c. mbaue
'swinging'
d. gaue
'it's cooked'

The number of words that have a three-vowel structure [aue] is limited. At the time of writing this paper, the words found were as shown in the data (17). The word kaue, bhaue, is an invented word, whose root word $\{u e\}$ 'swing, veins' gets the prefix $\{k a-, b h a\}$ and allomorph $\{m b a-\})$, while the word gaue is an invented word whose root word has the suffix noun/singular third person $(-e)$.

\section{Three-vowel cluster [eue]}

Data 18
a. nеие
'she's swinging'
b. теие 'you swing'
c. deue 'they swing'

Words that have a three-vowel cluster with the [eue] structure are very limited, only three words have been found as shown in the data (18).

\section{Three-vowel cluster [aie]}

\section{Data 19}

$\begin{array}{lll}\text { a. } & \text { paie } & \text { 'no' } \\ \text { b. } & \text { gaie } & \text { 'you swing' } \\ \text { c. } & \text { naie } & \text { 'they swing' } \\ \text { d. } & \text { saie } & \text { 'strike' } \\ \text { e. } & \text { kaie } & \text { 'hook' } \\ \text { f. } & \text { bhaie } & \text { 'accompany' } \\ \text { g. hamaie } & \text { 'where' }\end{array}$

The vowel cluster in data 19a occurs from the word paise. In usage, usually the consonant [s] tends to be carried out. Meanwhile, the group of consonants in data 19 (b, c, d, e, f, g) occurs from the root gai, nai, sai, kai, bhai, hamai and gets the third singular object / persona marker suffix $\{-\mathrm{e}\}$.
Three-vowel cluster [oie]
Data 20

$\begin{array}{ll}\text { a. koie } & \text { 'don't' } \\ \text { b. roie } & \text { 'a kind of grass' } \\ \text { c. soie } & \text { 'weaving' }\end{array}$

The vowel cluster in data 20a occurs from the word koise. In usage, usually the consonant [s] tends to be carried out. The vowel cluster in data $20 \mathrm{~b}$ occurs from the root word roie, the vowel cluster in data 20c occurs from the root soi which has a single third noun / persona suffix $\{-\mathrm{e}\}$.

Three-vowel group [eie]

Data 21
a. keie
'teriaki'
b. teie
'put / save'
c. reie
'put your fingers up'
d. weie 'tripe'

Vowel cluster in data 21 (eie) occur from the root words kei, tei, rei, and wei, which end in a single third person/noun signifying $\{-\mathrm{e}\}$. 


\section{Three-vowel cluster [iue]}

Data 22

$\begin{array}{lc}\text { a. diue } & \text { 'ridiculous' } \\ \text { b. giue } & \text { 'search' } \\ \text { c. liue } & \text { 'skip' } \\ \text { d. fesiue } & \text { 'sent aside' }\end{array}$

Vowel clusters in the 22abc data, (iue) occur from the root diu, giu, liu, getting the third person singular suffix $\{-\mathrm{e}\}$. Meanwhile, the group of vowels in the $22 \mathrm{~d}$ data, (iue) occurs from the siu root word 'edge' that gets the prefix $\{\mathrm{fe}-\}$ and gets the third singular noun / persona marker suffix $\{-\mathrm{e}\}$.

\section{Three-vowel cluster [oue]}

Data 23
a. kupoue
'carrying the back'

A word that has a three-vowel cluster with the [oue] structure is found only one word as shown in the data (23).
Four-vowel clusters [aeue]
Data 24
b. aeue
'I swing'
c. daeue
'we /they swing'
d. taeue
'we swing'
e. naeue
'she is swinging'

Words that have a four-vowel cluster with the structure [aeue] are found only for words that are in data 24. The words aeue, daeue, taeue, naeue are invented words, whose root word \{ue $\}$ 'swing, veins' preverbal persona $\{$ ae-, dae-, tae-, nae- $\}$.

\section{Five-vowel clusters [aeuea]}

\section{Data 25}
a. аеиеа
'I swing'
b. daеuеa
'we/they swing'
c. taеuеa
'we swing'
d. naeuea 'she swing'

The words aеuea, daeuea, taeuea, naeuea are invented words, whose root \{ue\} 'swing, veins' gets preverbal $\{\mathrm{ae}-$, dae-, tae-, nae- $\}$ and a postposition ending $\{-\mathrm{a}\}$.

\section{Six-vowel cluster [aeueue]}

Data 26
a. аеиеие
'I am swinging around'
b. паеиеие 'she iis swinging around'
c. tаеиеие 'we are swinging'
d. daeueue 'we rocked'

Words that have a cluster of six vowels with a [aeueue] structure are the words that exist in the data 26. The words аеиеие, даеиеие, tаеиеие, паеиеие are invented words, whose basic form \{ueue\} 'swinging' gets preverbal $\{$ ae -, nae-, tae-, dae-\}.

\section{Seven-vowel clusters [aeueuea]}

Data 27
a. аеиеиеа
'I am swinging around'
b. паеиеиеа 'she is swinging around'
c. tаеиеиеа
'we swing around'
d. daечеиеа
'we /they swing around' 
The words that have a group of seven vowels with the structure [aeueuea] are only words that exist in data 27. The words аеиеиеа, паеиеиеа, tаеиеиеа, dаеиеиеa are invented words, whose basic form \{ueue\} 'swinging' gets preverbal $\left\{a e-, n a e-, t^{2}-\right.$, dae- $\}$ and the suffix $\{-\mathrm{a}\}$ as particles.

\section{Eight-vowel cluster [aeueueue]}

\section{Data 28}

a. аеиеиеле 'I am swinging around'

b. паемеиеие 'she is swinging around'

c. tаеиеиеие 'we swayed'

d. daеиеиеие 'we/they are rocking'

The words that have a group of seven vowels with the structure [aeueuea] are the words that exist in the data 28. The words аеиечеие, паеиечеие, tаечеиеие, dаеиечеие are invented words, whose basic form \{ueueue\} 'swinging' gets preverbal \{ae -, nae-, tae-, dae-\}.

\section{Nine-vowel clusters [aeueueue]}

\section{Data 29}
a. аеиеиеиеа
'I am swinging around'
b. паеиеиеиеа 'she is swinging around'
c. tаечечеиеа 'we rocked'
d. daеиеиеиеа 'we/they swing around'

Words that have a cluster of seven vowels with the structure [aeueueue] are only words that exist in the data 29. The words аеиеиеa, паеиеиеиеа, tаеиеиеиеа, даеиеиеиеа are invented words, whose basic form \{ueueue\} 'swinging' gets preverbal \{ae -, nae-, tae-, dae-\} and the -a suffix as particles.

\section{Conclusion}

a. The Muna language has a two-vowel cluster with a free structure. The vowel [i] can be in front of and behind the vowel [ieauo], the vowel [e] can be in front of and behind the vowel [ieauo], the vowel [a] can be in front of and behind the vowel [ieauo], the vowel [u] can before and after the vowel [ieauo], the vowel [o] can be in front of and behind the vowel [ieauo].

Table 1. Posisi Vokal dalam Gugus Dua Vokal

\begin{tabular}{cccc}
\hline & \multicolumn{3}{c}{ Posisi } \\
\cline { 2 - 4 } Vokal & Awal & Tengah & Akhir \\
\hline $\mathrm{i}$ & $\mathrm{i}$ & $\mathrm{I}$ & $\mathrm{I}$ \\
$\mathrm{e}$ & $\mathrm{e}$ & $\mathrm{e}$ & $\mathrm{E}$ \\
$\mathrm{a}$ & $\mathrm{a}$ & $\mathrm{a}$ & $\mathrm{A}$ \\
$\mathrm{u}$ & $\mathrm{u}$ & $\mathrm{u}$ & $\mathrm{U}$ \\
$\mathrm{o}$ & $\mathrm{o}$ & $\mathrm{o}$ & Oo \\
\hline
\end{tabular}

b. Muna language has three-vowel cluster, four-vowel cluster, five-vowel cluster, sixvowel cluster, and seven-vowel cluster with a dependent structure and a very limited number of vocabularies that have these vowel cluster.

c. In the cluster of three vowels, the one that can take the initial position is [i e a u o], which can take the middle position is [i e a u], the vowel that can take the final position is $[\mathrm{e} \mathrm{a} \mathrm{u}$. Three-vowel chart can be seen in the following chart. 
Table 2. Posisi Vokal dalam Gugus Tiga Vokal

\begin{tabular}{cccc}
\hline & \multicolumn{3}{c}{ Posisi } \\
\cline { 2 - 4 } Vokal & Awal & Tengah & Akhir \\
\hline $\mathrm{i}$ & $\mathrm{i}$ & $\mathrm{i}$ & - \\
$\mathrm{e}$ & $\mathrm{e}$ & $\mathrm{e}$ & $\mathrm{E}$ \\
$\mathrm{a}$ & $\mathrm{a}$ & $\mathrm{a}$ & $\mathrm{A}$ \\
$\mathrm{U}$ & $\mathrm{u}$ & $\mathrm{u}$ & $\mathrm{U}$ \\
$\mathrm{o}$ & $\mathrm{o}$ & - & - \\
\hline
\end{tabular}

d. In cluster of four vowels to cluster of nine vowels, the vowel that can take the initial position is vowel [a]. The vowel that can take the middle position is [e u]. Meanwhile, the vowel that can take the final position is the vowel [e]. It can be seen in the following chart.

Table 3. Posisi Vokal dalam Gugus Empat s.d Sembilan Vokal

\begin{tabular}{cccc}
\hline & \multicolumn{3}{c}{ Posisi } \\
\cline { 2 - 4 } Vokal & Awal & Tengah & Akhir \\
\hline $\mathrm{i}$ & - & - & - \\
$\mathrm{e}$ & - & $\mathrm{e}$ & $\mathrm{E}$ \\
$\mathrm{a}$ & $\mathrm{a}$ & - & $\mathrm{A}$ \\
$\mathrm{u}$ & - & $\mathrm{u}$ & - \\
$\mathrm{o}$ & - & - & - \\
\hline
\end{tabular}

\section{Reference}

[1] Artawa, Ketut dan Jufrizal. 2018. Tipologi Linguistik. Pustaka Larasan.

[2] Anceaux, J.C. The Wolio Language. 1988.Dordrecht-Holand/Providence U.S.A.: Foris Publications.

[3] Fatinah, St. "Sikap Bahasa Etnik Muna di Perantauan Sulawesi Tengah." Prosiding. Kantor Bahasa Provinsi Sulawesi Tenggara.

[4] Kamaludin, Dkk. 2016. Bahasa Wolio, Riwayatmu. Kendari: Universitas Halu Oleo Press.

[5] La Ode Nggawu. 2015. "The Genetic Relationship beetwin Tongkuno and GuMawasangka Dialects of Muna Language in Southeast Sulawesi ." Denpasar: Universitas Udayana.

[6] Mahdin. 2015. "Pelestarian Bahasa-Bahasa Daerah Sulawesi Tenggara Melalui Pendidikan Formal (Reposisi Pembelajaran Bahasa Daerah dalam Kurikulum 2013)" Prosiding. Kantor Bahasa Provinsi Sulawesi Tenggara.

[7] Mahsun. 2015. "Strategi Pemertahanan Bahasa Daerah." Prosiding Kantor Bahasa Provinsi Sulawesi Tenggara.

[8] Mappau, R. 2013. "Penggunaan Bahasa Remaja." Kandai: Jurnal Bahasa dan Sastra.(Vol. 10 No. 2).

[9] Marafad, La Ode S., 2004. "Pronomina Persona Bahasa Muna" (Disertasi). Universitas Padjadjaran.

[10] Marafad, La Ode S., 2012. Pelajaran Bahasa Muna (Muatan Lokal) untuk Siswa Kelas 1 s.d. Kelas 6 SD. 
[11] Marafad, La Ode S., 2012. Pelajaran Bahasa Muna (Muatan Lokal) untuk Siswa Kelas 1 s.d. Kelas 3 SMP.

[12] Marafad, La Ode S. 2015. "Strategi Pembelajaran Bahasa Daerah". Prosiding. Kantor Bahasa Provinsi Sulawesi Tenggara.

[13] Marafad, La Ode S., 2015. "Peran Semantis Pronomina Persona Bahasa Muna." Retorika: Jurnal Ilmu Bahasa, (Vol. 1 No. 1).

[14] Marafad, La Ode S., 2015. "Ungkapan Falia dalam Konteks Pendidikan Karakter AAnak pada Etnik Muna di Kabupaten Mnua, Sulawesi Tenggara.” Proceeding the $7^{\text {th }}$ International Seminar on Austronesian-Non Austronesian Languages and Literature. Denpasar: Universitas Udayana.

[15] Marafad, La Ode S., dan Nirmala Sari. 2016. Falia (Pemali). Jogyakarta: Pustaka Puitika.

[16] Meko Mbete, Aron Dkk. (Penyunting) 2007. Bahasa Ibu, Fungsi, Kondisi, Revitalisasi: Pemberdayaan Bahasa Indonesia dan Bahasa-Bahasa Nusantara sebagai Bahasa Ibu. Bali: Universitas Udayana.

[17] Mulawati. 2014. "Aspek Sosiologis Nyanyian Pengantar Tidur Rakyat Muna.." Kandai: Jurnal Bahasa dan Sastra. (Vol. 10 No. 2).

[18] Van den Berg. 1998. A Grammar of the Muna Language. Nederland.

[19] Yamaguchi, M. 2012. Penelitian Bahasa Daerah Pulau Sulawesi Bagian Selatan di Indonesia..Kyoto, Jepang: Hokuto Publishing Inc. 